\title{
A NEED FOR NATIONHOOD
}

VOLUME 13, NOS. 7.8 JUL.AUG, 1970

\begin{abstract}
WORLDVIEW is published monthly [except for a combined July-August issue] by the Council on Religion and International At. fairs. Subscription $\$ 4.00$ for one year; $\$ 7.00$ for two years; $\$ 9.00$ for three years.
\end{abstract}

Address: 170 East 64th Street, New York, New York 10021. TE $8 \cdot 4120$

\section{EDITORIAL BOARD \\ James Finn: Editor \\ John R. Inman \\ A. William Loos \\ Editorial Assistants: \\ Susan Woolfson \\ Kip Zegers}

Contributing Editors: Donald Brandon, Jerald C. Brauer, Ernest W: Lefever. Bernard Murchiland, Edmund Stillman

\section{CONTENTS}

In the Magazines

A Need for Nationhood

Alan Geyer

Education for. What?

Kenneth W. Thompson Editorials

The Forms of Power Wilson Carey McWilliams

The Climate of Nihilism Bernard Murchland

Spirituality and Politics James V. Schall

Vietnam-and Beyond Donald Brandon

"The Perils of Reform. Intervention" Cont'd.

" 'Can the Violent Bear it Away?' " Corresporidence

Roadore are rominded that worldviow wolcomes correspondonce. Letters may bo opelfic com. monts on erticios in recent lesues of enporal dis. cuesion, but rosders are requested to limit their lotters to 800 words.

Opinions expreseid in worldviow are those of the guthors, and not neceasarily of the Council on 1978 Councli on Refiglon and internationaly
Polarization is no longer an adequate word for what is happening in America these days. Try words like splintering, fragmentation, disintegration: these tell the story a little better. This nation is more broken in its relationships, more shattered in spirit, than at any time since the Civil Warr. All our institutional glue has come unstuck. Goverument is aimless, law has lost authority, political parties are in clecay, our cities are groping in fear and filth, on exomomy is in the absurd clutches of an inflationary recession, higher education has its back to the ivied walls, religious loyalty and organiztion is in rapid dissolution.

The measure of either religious pertinence or political relevance must now lie in the capacity to deal with this brokenness among our people. For if we do not soon find the cement of comnon justice, of human solidarity and of peace. we shall find ourselies plunged back into the barbaric state of man which Thomas Holbbes called "solitary, poor, nasty, brutish, and short."

There is no short-circuiting the imperative of creating a new and more humane nationalism in Americia. Nor can our nation's wounds be bound up by pretending that nations don't count for anything anymore in our global village. 'In many parts of the world today, the struggle for mationhood-for self-respect, self-determination, and a new coherence of culture and institutions-largely defines the struggle for humanization. Why should we pretend that the United State's is exempt from the requirements of that struggle?

I do not apologize for saying that we must get alont the business of our own nationhood. Pulling this nation together now calls for resources of mind and soul which no church, no university, no political party or movement, no court chaplains in the White House can trifle over if they are to touch the depths of our brokenness.

We are wrong to assume that there ever was a time when national unity could be taken for granted in the U.S. Except in times of world war, or frenzied international cxploits, we have usually seemed like a great aggregation of petty principalities in which locial patriotisms, sectional, economic, and racial interests have really been more important to us than national identity. No people have ever damned their own national government more regularly than we have, and that usually with a burst of phony patriotic rhetoric. Our nationhood is not so much a fact of our past as it is a moral achievement yet to be realized in the future.

We have been broken from the very heginning because some of our founding fathers tried to build a civilization on the cruel quicksands of Negro slavery. And, to this latest generation, we are tormented, black and white alike, by our inability to re-establish ourselves on the solid common ground 
of the human ecquality which is professed so eloquently in our own Decdaration of Independence.

Tou often-hecaluse we do not really take hisfory very seriously-we settle for the cheapest myths as to what our natiomal pilgrimage really moans, and what it really promises. We become the living proof that T. II. IIuxley's funny definition mav he serious after all: "A nation is a people mited by a common error ats to its origins and a common aversion to its neighbors."

A truly free people is open to erery possibility that its dissenters may own a better definition of mationhood than its officialdom. There is a very precious tom in the British political rocabuliary: the "lonal Opposition." Ilow quick we are to assume, in Amcricin public debate, that opposition is disloyal. And how often we have been obliged to recognize, in retrospect, that dissenters may halve hatd a much more majestic and humane sense of mational lovalty than those who called them "traitors."

In the cisce of Martin Luther King, Jr., in spite of all the suffering of his people and in the face of the death he knew awated him, he conk yeet sily: "I still have a dream. It is a dream that is deeply rooted in the Americall dream. I have a dream that one day this nation will rise up. live out the true meaning of its creed: . . that all men are created c(puial."

Ilaving heen so lunresponsice to a black apostle of mon-violenere who identified so profoundly will the symbols of the American heritage, white America can now hardly be surprised, and certainly not self-righteous, if some of their black follow-citizens are doubtful alont the philosophy of non-violence and offended by appeals to patriotism. For some blacks and some young whites, the alienation from any meaningful sense of belonging (o America is almost complete. No patriotic excreises or exhortations will recall them. Justice and peace might bring them back.

Whaterer the tasks of politics and the arts in the reconstruction of freedom in Americat, the churehes are surely called to share the burdens of nitionloosed. It ought to be possible to imagine the churches-of all institutions-serving the perople at the very places where communities are most shatlered, where personal reliationships are most estranged, where men and women do not know yet that creativity is a God-given necessity of their heing, where justice is denied, where children are robbed, where healing is desperately needed.

Where churches do these things, we need not wory too much about their evangelical power to attract the younger generation. But this generation has become a plumbline for the testing of authenticity in the Christian faith. Where churches continue to fly the Christian and the American Hags side-by-side in their sanctuaries, but do not share the burdens of our broken and unfulfilled nationhood, the future of those churches is very bleak-as it should be.

Above all, the churches must cease to hold to such a cramped view of what it means to be "spiritual" in a society which must forever struggle to be truly free.

Alan Geyer

\section{EDUCATION FOR WHAT?}

A great philosopher in another age proclaimed that survival was a race between education and destruction. Yet to restate this leaves unanswered the question, "education for what?" The Germans under Hitler were a highly cultured people yet wreaked destruction on the world; our own consciences are uneasy after Hiroshima and Nagasaki.

The question turns in part on the meaning and purposes of education. From the standpoint of a democracy, we have linked education to the open socicty and to open minds on whom it depends. The educated man, we say, is sensitive to alternatives and aware of consequences. $\mathrm{He}$ is an agent of change and an instrument of progress. This notion of education for responsibility presupposes both process and purpose, for openness is based on some form of commitment, whether to science, progress, or truth. We can afford to be open because there are moorings and benchmarks. With Willium James we can say: "It is not thinking with its primitive ingenuity of childhood that is most difficult but to think with tradition, with all its accuired force. ..."

This answer to the timeless question, "education for what?" has been "sufficient to the day." It has accorded more or less with the trends of the time and the spirit of the people. Now we find ourselves in a world rent by social and biological revolutions, sweeping alterations in interpersonal and national moods. We have less time to ponder and less willinguess to forgive or forget or to practice. restraint. Life styles for many have visibly changed, and for many more there are far-reaching questionings and doubts about who we are and where we are going. This growing movement presents us with questions that outnumber answers. We camnot be clear which aspects are trans-

+ norlduinu 